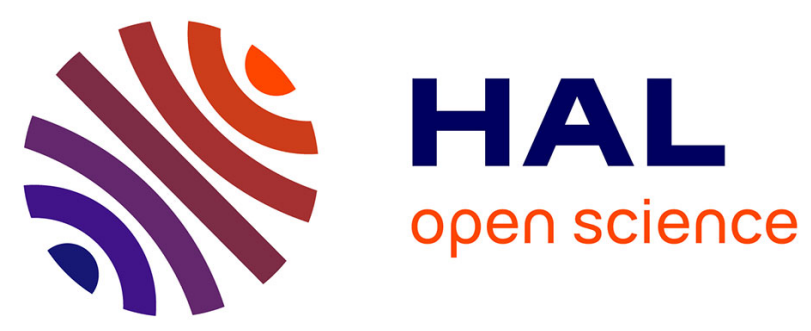

\title{
Integrating ICT in Pre-service Teacher Education in Zanzibar: Status, Challenges and Opportunities
}

\author{
Umayra El Nabahany, Said Juma
}

\section{To cite this version:}

Umayra El Nabahany, Said Juma. Integrating ICT in Pre-service Teacher Education in Zanzibar: Status, Challenges and Opportunities. 1st International Conference on Sustainable ICT, Education, and Learning (SUZA), Apr 2019, Zanzibar, Tanzania. pp.117-124, 10.1007/978-3-030-28764-1_14 . hal-02515729

\section{HAL Id: hal-02515729 \\ https://hal.inria.fr/hal-02515729}

Submitted on 23 Mar 2020

HAL is a multi-disciplinary open access archive for the deposit and dissemination of scientific research documents, whether they are published or not. The documents may come from teaching and research institutions in France or abroad, or from public or private research centers.
L'archive ouverte pluridisciplinaire HAL, est destinée au dépôt et à la diffusion de documents scientifiques de niveau recherche, publiés ou non, émanant des établissements d'enseignement et de recherche français ou étrangers, des laboratoires publics ou privés. 


\title{
Integrating ICT in Pre-Service Teacher Education in Zanzibar: Status, Challenges and Opportunities
}

Umayra El Nabahany [0000-0003-0567-2079] and Said Juma [0000-0001-5999-3236]

State University of Zanzibar, SUZA, Zanzibar, Tanzania

\{umayra.al-nabhany, said.juma\}@suza.ac.tz

\begin{abstract}
The notion of integrating ICT in education has proven to provide various solutions to educational issues. Preparing pre-service teachers for ICT integration has been crucial in many teacher training colleges and universities. The present paper with preliminary data findings explores the status, challenges and opportunities that exist in the integration of ICT tools in pre-service teacher education at the State University of Zanzibar. This was a mixed study that employed both qualitative and quantitative methods. However, the major approach used was quantitative. Initial findings indicate that despite SUZA having its own updated Learning Management System (LMS) and ICT tools and infrastructures, there are still many challenges related to infrastructures, readiness, ICT skills and comfortability in integrating ICT tools in teaching and learning. In addition, the paper explores the many opportunities that are available at the State University of Zanzibar in the integration of ICT in education particularly in pre-service teacher education.
\end{abstract}

Keywords: ICT; learning; teaching; pre-service teachers; teacher education; Zanzibar..

\section{Introduction}

The integration of Information and Communication Technology (ICT) in pre-service teacher training has been gaining currency worldwide since the advent of the 21st century. Research suggests that effective use of ICT can enhance teaching and learning among pre-service teachers [1, 2]. Preparing pre-service teachers for ICT integration has been crucial in many teacher training colleges and universities [3, 4]. [5] argue that pedagogical knowledge and content knowledge are not enough to make teachers effective. Teachers need to be trained to integrate ICT with pedagogy and content into teaching through a combination of knowledge of technology. Separate courses on ICT may not be enough for an effective ICT integration in teacher education [6]. Such a course needs to be accompanied with other strategies such as elearning policy; and an institutional strategy to improve and encourage the use of ICT technologies in teaching and learning [7].

In Tanzania, an extensive research has been done on the use of ICT for teaching and learning among university students in Tanzania [8]. However, there are regional variations as well as differences in uptake technology integrations at institutional 
levels. For example, little is known about the exact capacity of SUZA academic staff to integrate ICT for pre-service teacher education. Furthermore, it is not clear what are the perceived challenges and opportunities of integrating ICT in pre-service teacher education. Thus the present study was set to explore SUZA's ICT capacity and the process of integrating ICT into pre-service teacher education. In the remaining parts of this paper, we first present the background and context of the study followed by the purpose of the study, the study objectives, research questions, study design and conceptual framework. We then proceed with the description of the methodology of the study and presentation and discussion of the findings from both the quantitative and qualitative data. Finally we provide some recommendations which may have a number of practical implications for future practice in the study context.

\section{Background and Context of the Study}

This research explored the process of integrating ICT into pre-service teacher education in Zanzibar - a semi-autonomous part within the United Republic of Tanzania. The study was conducted at Tunguu campus (located in the South Region) and Nkrumah campus (located in the Urban West Region) of the State University of Zanzibar.

The State University of Zanzibar (SUZA) is one of the youngest universities in the region, but by far one of the fastest growing in the region. SUZA has 6 schools at the moment namely School of Natural and Social Sciences, , School of Education, School of Kiswahili and Foreign Languages, School of Continuing and Professional Education, School of Health and Medical Sciences, and School of Business. New schools in the pipeline include School of Petroleum and Engineering, School of Computing, Communications and Media, School of Agriculture and School of Tourism Development.

School of Education gets a majority of students studying to be teachers compared to any other school at SUZA per year. For instance, data from Department of Quality Assurance indicate that in 2016/17 the number of registered students for Bachelor's degree only was 396, out of that number 216 were students taking education courses. The School also offers some programmes to students taking other degrees particularly from the School of Natural and Social Sciences and School of Kiswahili and Foreign Languages. Majority of students specializing in education programmes have limited ICT literacy skills compared to those in other specializations.

The university has been striving to ensure proper teaching and learning environments for the 21st century learners at SUZA. Academicians are constantly trained to create teaching and learning content that integrates technology. The university has put the infrastructure and facilities such as computer labs with access to the internet and Wi-Fi access across the university. A Learning Management System (LMS) has been used since 2011 with the assistance from partner university of Copenhagen through a Building Stronger University Project. A number of courses at SUZA are utilizing the LMS through Blended Learning and E-Learning teaching approaches. Additionally, the university has successfully initiated a Centre for Digital 
Learning which records and airs teaching programmes to help the students across Zanzibar. The university is currently developing a first ever Kiswahili Massive Open Online Course (MOOC) which will soon be available online for the learners. Moreover, the university has created an Open Educational Resource (OER) guideline as well as ICT policy which is followed at the university.

Currently, more than 300 courses are available on the Learning Management System even though they are not fully utilized due to many challenges. These challenges are related to both to course instructors preferring face to face mode of teaching as well having insufficient IT skills which is a major requirement to utilize online platform fully. In a survey carried out by [9], it was noted that there were difficulties in the preparation of teachers to integrate technology in the classroom due to the following reasons: (1) many teachers, while having access to technology in school, said they do not make use of them in teaching. (2) the majority of teachers are not ready to use and create the resources for teaching and learning using technology particularly those related with the use of the computer. (3) most of the activities carried out with the computer affect their physical and mechanical use, rather than the integration of technology into the curriculum.

Students on the other hand, apart from having basic IT skills needed to use the Learning Management System, they are still not motivated to use the LMS for their courses. The poor internet connections, insufficient access to ICT tools also make it difficult for SUZA to fully integrate technology in teaching and learning.

\section{Purpose of the Study}

To explore the use and integration of ICT into pre-service teacher training at the State University of Zanzibar.

\subsection{Objectives}

To achieve the aforementioned purpose, the study was guided by three objectives:

1. To examine the use of ICT in pre-service teacher education

2. To explain the current status and challenges of integrating ICT in pre-service teacher education and

3. Put forward a framework to help SUZA integrate ICT in learning and teaching for pre-service teachers.

\subsection{Research Questions}

To reach these objectives, the study attempted to answer three research questions namely:

1. What ICT resources are accessible to the preservice teachers at SUZA?

2. How/to what extent do the pre-service teachers at SUZA use the available/accessible ICT resources? 
3. What are the constraining factors for ICT integration among pre-services teachers at SUZA?

4. What are the constraining factors for ICT integration among lecturers in preservice teacher training?

5. What framework can be designed for ICT integration amongst pre-service teachers at SUZA?

\subsection{Study Design}

The study aimed to gain a deep insight and intensive analysis of the use of ICT among the University students. Thus, it employed a case study design [10, 11]. The State University of Zanzibar was selected as a case study to gain an in depth understanding of the integration of ICT into the pre-service teacher training. The study therefore did not aim to compare or generalise its findings to other Universities or similar institutions.

\subsection{Conceptual Framework}

We have adopted [5] conceptual framework on integration of technology into teachers' pedagogical knowledge. [5] added technology (e.g. projector, mobile phone, iPad) on Shulman's Pedagogical Content Knowledge and proposed the concept of Technological Pedagogical Content Knowledge (TPCK), which is concerned with use of technology for teaching and learning speci?c contents. The framework includes a complex interplay among four constructs namely (1) Pedagogical Content Knowledge; (2) Technological Pedagogical Knowledge; (3) Technological Pedagogical Content Knowledge and (4) Technological Content Knowledge. In this framework, [5] maintain that teacher education should enable teachers to have an understanding of how technology influences pedagogy and content. In the same vein, [12] emphasizes that 'The goal of teacher education is not to indoctrinate or train teachers to behave in prescribed ways, but to educate teachers to reason soundly about their teaching as well as to perform skilfully' (p.13).

In this framework the main argument is that mere presence or introduction of technology in educational institutions such as schools or universities is not sufficient. Of more importance is how the technology is integrated and used to enhance teaching and learning among teachers.

The TPCK framework assumes that 'learning environments that allow students and teachers to explore technologies in relationship to subject matter in authentic contexts are often useful' (Ibid p.1045)

\subsection{Data, data collection instruments and study participants}

Both primary and secondary data were used in this study. Primary data included both qualitative and quantitative data which were mainly collected through a survey method. Three online questionnaires were used to collect data from the pre-service teachers $(\mathrm{N}=123, \mathrm{f}=86, \mathrm{~m}=37)$; Heads of department from the School of Education 
and the School of Natural and Social Sciences $(\mathrm{N}=4, \mathrm{f}=1, \mathrm{~m}=3)$; and Lecturers $(\mathrm{N}=6$, $\mathrm{f}=3, \mathrm{~m}=3$ ). The students were either provided with iPads or asked to use their smartphones to access the online questionnaire. The lecturers and the heads of department respondents used their laptops, smartphones or desktop computers to respond to the questionnaires.

\subsection{Data analysis}

We used Microsoft Excel and Tableau Desktop 2018 to analyse the quantitative data from the Google Forms. Tableau, provides an easy and faster drag-and-drop approach to visual analysis of Excel spreadsheet data that was obtained through Google Forms. For the qualitative data we used Thematic Content Analysis [13]

\section{$4 \quad$ Findings}

\subsection{Existence of ICT policy}

The heads of departments were asked to respond whether SUZA has its own written statement on the use of ICT. Only one respondent knows about the existence of the policy and the rest do not know. This suggests that even if the policy statement might exist, it is not known to other heads of departments.

\section{Using ICT for pedagogical purposes}

The data has shown that only one respondent out of 4 knows about written statement specifically about the use of ICT for pedagogical purposes. Three of the respondents indicate that there is no such policy at SUZA and one does not know if it exists or not.

\section{Integrating ICT in teaching}

When the lecturer respondents were asked if they integrate ICT tools in their teaching, four of the respondents said yes and two indicated to do that sometimes. For those who answered yes to integrating ICT tools in their teachings, their reasons were: "It is easy especially by using social media, it is easy to engage the student directly in the learning process."; "It simplify my teaching seeing several examples from YouTube"; "There are limited Knowledge of ICT programs". And for those who said they sometimes integrate ICT tools in their teaching, their reasons were: "During preparation, searching materials and in classroom instructions become easier", 


\section{Search the internet to collect information}

Majority of the respondents 5 out of 6 indicated that they use internet almost or everyday to search for information online while 1 respondent out of 6 does this several times in a month. Interestingly, when asked on the frequency of using computers to create blogs or discussion forums for students, one respondent indicated to use that once in a week and 5 of the respondents indicated to have never done that.

\section{Challenges of integrating ICT tools in teaching at SUZA}

The respondents were asked to mention challenges if there are any that are likely to be faced by SUZA academic staff in integrating ICT tools in their teaching. The answers given included poor network; many of the students are not conversant with computer; students are not motivated to use LMS, many of them prefer social media like Facebook; sometimes internet is so slow; unreliable electricity; and shortage of few resources such as computers.

\section{Opportunities in integrating ICT tools in teaching at SUZA}

The respondents indicated that there are several opportunities can make integration of ICT tools in teaching easier. The opportunities mentioned included presence of LMS, and availability of power; getting materials from other universities; awareness amongst staff on the need for ICT integration and the presence of ICT experts around all the SUZA campuses.

\section{ICT tools and comfortability of using them}

Data show that of all the surveyed respondents, the majority of the pre-service teachers (99\%) have access to one or more tools of ICT technologies for learning. Smartphones and laptops were the most popular ICT tools that are owned and used for learning amongst the pre-service teachers. Data show that 97 (78.9\%) own and use smartphones. With regard to comfortability of using these ICT tools, many of the respondents were comfortable whereby 56 (45.5\%) felt very comfortable with using ICT tools for learning, 33 (26.8\%) felt a little comfortable, 31 (25.2\%) felt fairly comfortable, and only 3 (2.4\%) were not comfortable at all.

\section{Skills of Using ICT tools}

The respondents were asked to mention whether they have enough skills in using the ICT tools in their studies. Many of them (60.2 \%) said that they do not have enough skills while only $39.8 \%$ claimed to have enough ICT skills for their studies.

\section{Access and Connection to internet while at SUZA}

The findings reveal that $86 \%$ of the pre-service teachers have access to internet while at SUZA. The most popular source of connection according to the majority (111) of the respondents (90.2\%) is SUZA Wi-Fi while mobile data was mentioned as the second most common source of connection to internet. 


\section{Using IT technologies in the classroom environment}

The respondents were asked to give their views about using IT technologies in the classroom. There were differing responses on this theme. Many of them acknowledged the importance of ICT for improving teaching and learning but also raised several concerns such as:

"ICT services in SUZA especially school of Kiswahili are very poor. We had no access to LMS in whole first year, and in this year only one lecturer used it";

"Not all the instructors of SUZA are interested in using ICT because some of them don't have the skills towards ICT and they don't want to use the resources." " "The lecturers should try to use simple terms and should not speak too first during the lectures because ICT needs more practice than theory. Of more importance is also the need for those responsible to repair the computers which are not working."

These study findings reveal the actual current situation regarding the use and integration of ICT into pre-service teacher training at the State University of Zanzibar. Generally, the findings show that there is very little integration of ICT due to various factors. The findings also indicate the shortage of various ICT equipment to enhance teaching and learning at the University. These findings may contain important implications for improving the use of ICT technologies in order to enhance teaching and learning of the pre-service teachers at the study context.

\section{$5 \quad$ Concluding Remarks and Recommendations}

Integration of ICT into pre-service teacher training at the State University of Zanzibar has still got a long way to go despite several initiatives taken. Both students and the staff have reported a number of challenges which hinder effective ICT integration. These include unreliable internet services, shortage of ICT facilities like computers, having staff who are unmotivated to integrate ICT in their teaching methodologies, and few opportunities of ICT training for the students. In addition, the existing ICT policy is not adequately shared to the staff members. This study has focused on the integration of ICT in pre-service teacher training. We posit according to [5] framework that effective pre-service teacher preparation should be cognizant of the need to integrate ICT in the pre-service teacher training. Both pre-service and inservice teacher need to be empowered to effectively integrate ICT in their teaching. Thus, pre- service teachers should start to experience how such integration can be done right from their teacher training institutions rather than experiencing it as an add on when they begin their career in schools.

Based on the study findings, we put forward some recommendations which may contribute to improve the process of integrating ICT into pre-service teacher training.

The ICT policy should be shared to all staff. This will help to ease an effective and collaborative implementation of the policy. It is also worth considering the need to review the ICT policies to keep abreast with rapid pace of technological advancement. For a more effective integration of ICT into the pre-service teacher education, SUZA may wish to consider preparing ICT guidelines for integration of ICT in teaching and 
learning with clear implementation plan and sufficient will to support the implementation from the University Management.

As the study findings have indicated a shortage of ICT facilities including computers, there is, therefore, a definite for SUZA to enhance availability and accessibility of technological facilities for both the students and the staff. Greater efforts are needed to ensure the School of Education prioritizes technologies and infrastructures to be used by all pre-service teachers at the University and their prospective schools during their practice teaching in schools.

Ensuring appropriate ICT systems, services (e.g. increasing broadband access) and support for the students and the staff should be a priority. This should include continuing professional development opportunities of teachers and academicians in ICT integration for teaching and learning.

Another important practical implication of the study findings is that there is a need for developing a policy about using social networks (e.g. Facebook, WhatsApp etc.) in teaching and learning to avoid unintended and unethical use of the networks amongst both students and the academics. In addition, the academicians who integrate ICT tools in their teaching (e.g. using LMS, making their courses online) can be motivated through promotion or other ways to encourage them to integrate ICT into their teaching methodology.

\section{References}

1. Tondeur, J., Van Braak, J., Sang, G., Voogt, J., Fisser, P., \& OttenbreitLeftwich, APreparing pre-service teachers to integrate technology in education: A synthesis of qualitative evidence. Computers \& Education, 59(1),134-144 (2012).

2. Farjon, D., Smits, A., \& Voogt, J. Technology integration of pre-service teachers explained by attitudes and beliefs, competency, access, and experience. Computers \& Education, 130, 81-93 (2019).

3. Kisalama, R., \& Kafyulilo, A. C. Developing pre-service teachers' technology integration competencies in science and mathematics teaching: Experiences from Tanzania and Uganda. Makerere Journal of Higher Education, 3(2) (2011).

4. Harrington, R., \& Rhine, S. Digital tools for accelerating preservice teacher effectiveness. In Pre-Service and In-Service Teacher Education: Concepts, Methodologies, Tools, and Applications (pp. 926-955). IGI Global (2019).

5. Mishra, P., \& Koehler, M. J. Technological pedagogical content knowledge: A framework for teacher knowledge. Teachers college record, 108(6), 1017(2006).

6. Tondeur, J. Enhancing future teachers' competencies for technology integration in education: Turning theory into practice. In Seminar. net (Vol. 14, No. 2, pp. 216-224) (2018).

7. Dahms, M-L., \& Zakaria, H. L.). Institutional Capacities in E-learning and Problem Based Learning at Universities and University Colleges in Tanzania and Ghana. Department of Development and Planning, Aalborg University (2015). 
8. Mbalamula, Y. S. Role of ICT in Teaching and Learning: Influence of Lecturers on Undergraduates in Tanzania. education, 4(22), 24-25 (2016).

9. James, P. T. Mobile-Learning: Thai HE Student Perceptions and Potential Technological Impacts. International Education Studies (1999).

10. Creswell Research design: qualitative, quantitative, and mixed methods approaches. Sage Publications (2009).

11. Bryman, A. Social research methods. Oxford University Press (2008).

12. Shulman, L. Knowledge and teaching: Foundations of the new reform. Harvard educational review, 57(1), 1-23 (1987).

13. Clarke, V., \& Braun, V. Thematic analysis. In Encyclopedia of quality of life and well-being research (pp. 6626-6628). Springer, Dordrecht (2014).

14. Parkman, S., Litz, D., \& Gromik, N. Examining pre-service teachers' acceptance of technology-rich learning environments: A UAE case study. Education and Information Technologies, 1-23(2018). 